\title{
17-HYDROXYANDROGENS AND OESTROGENS IN THE PLASMA OF NORMAL AND INFERTILE MEN
}

\author{
M. S. WALKER, J. K. GRANT, R. SCOTT* AND J. SINCLAIR* \\ University Department of Steroid Biochemistry, and \\ *Department of Urology, Royal Infirmary, Glasgow G4 OSF
}

(Received 5th February 1975)

Androgens, particularly testosterone, have long been held to be controlling factors in spermatogenesis (Steinberger \& Ducket, 1967). Oestrogens have been shown to influence the output of pituitary gonadotrophins and thus cause Leydig cell atrophy. They also affect germinal cells in the seminiferous tubules directly (de la Balze et al., 1962).

In the present study, we have attempted to correlate the plasma concentrations of 17-hydroxyandrogens (17-OHA) and oestradiol-17 $\beta$ with the sperm counts and testicular histology of $134 \mathrm{men}$. All the men were referred to the infertility clinic with a history of at least 2 years of childless marriage during which regular intercourse, without contraception, had taken place.

On the patient's initial visit to the clinic, $10 \mathrm{ml}$ peripheral venous blood were withdrawn for steroid assays. The patients were instructed to collect semen samples by coitus interruptus in the morning after 3 days of abstinence from intercourse. The semen samples were delivered by the patient to the Urology Department within $1 \mathrm{hr}$ of collection.

When there were more than $60 \times 10^{6}$ spermatozoa $/ \mathrm{ml}$ which had $>95 \%$ normal morphology and $>50 \%$ motility $2 \mathrm{hr}$ after collection, the man was regarded as normal and no further investigations were carried out. Of the men tested, 46 men aged 24 to 36 years had sperm counts of $>60 \times 10^{6} / \mathrm{ml}$ (mean \pm S.D. $89.6 \times 10^{6} \pm 36 \times 10^{6} / \mathrm{ml}$ ), 31 men aged 22 to 33 years had sperm counts of $20 \times 10^{6}$ to $60 \times 10^{6} / \mathrm{ml}$ (mean $34.9 \times 10^{6} \pm 7.9 \times 10^{6} / \mathrm{ml}$ ), 43 men aged 21 to 35 years had sperm counts $<20 \times 10^{6} / \mathrm{ml}$ (mean $8.9 \times 10^{6} \pm 5 \cdot 1 \times 10^{6} / \mathrm{ml}$ ), and 18 men aged 21 to 31 years had no spermatozoa in the ejaculate. A total of 45 men, aged 21 to 35 years, underwent testicular biopsy performed under general anaesthesia. The scrotal skin was stretched over the testis and a small incision made. Gentle pressure to the testis caused a few tubules to protrude through the incision. With sharp dissection, these tubules were separated and placed gently into Bouin's fluid, with minimal trauma to the specimen (Charny, 1956).

Plasma for steroid assay was collected in lithium sequestrene tubes between 09.00 and 10.00 hours. If not analysed on the day of collection, plasma was stored at $-20^{\circ} \mathrm{C}$.

Sperm counts were performed with a haemocytometer within $2 \mathrm{hr}$ of collection. 
The 17-OHA were measured in an ether extract of $20 \mu \mathrm{l}$ plasma by a radioimmunoassay method similar to that of Hillier et al. (1973). An antiserum to testosterone-3-oxime-BSA was used. The only major cross-reactions in this system were testosterone $(100 \%)$ and $5 \alpha$-dihydrotestosterone $(80 \%)$. Betweenbatch precision with this assay was $6 \cdot 1 \%$ for a pool of mean \pm S.D. $6 \cdot 59 \pm 0.39$ $\mathrm{ng} / \mathrm{ml}$ (fifteen samples). Within-batch precision was $3.9 \%$ for a pool of mean $7 \cdot 86 \pm 0.31 \mathrm{ng} / \mathrm{ml}$ (ten samples). The mean water blank was $5 \pm 5 \mathrm{pg} / \mathrm{sample}$ (eighteen samples).

Oestradiol-17 $\beta$ was measured in an ether extract of $1 \mathrm{ml}$ plasma by a radioimmunoassay procedure similar to that for 17-OHA. The anti-oestradiol-17 $\beta$ 3-carboxymethyl-BSA serum used cross-reacted only with oestradiol-17 $\beta$ $(100 \%)$, oestrone $(16 \%)$ and oestriol $(<0.05 \%)$. Between-batch precision in this assay was $10 \%$ on a pool of mean \pm S.D. $93 \pm 10 \mathrm{pg} / \mathrm{ml}$ (twelve samples). Within-batch precision was $7 \cdot 1 \%$ on a pool of mean $42 \pm 3 \mathrm{pg} / \mathrm{ml}$ (ten samples). Water blanks were consistently $<5 \mathrm{pg} / \mathrm{ml}$ (twelve samples).

A comparison of the plasma 17-OHA levels in men with different sperm counts (Text-fig. 1a) showed that no significant differences in 17-OHA concentrations could be observed, and the data are in agreement with those presented by Lawrence \& Swyer (1974).
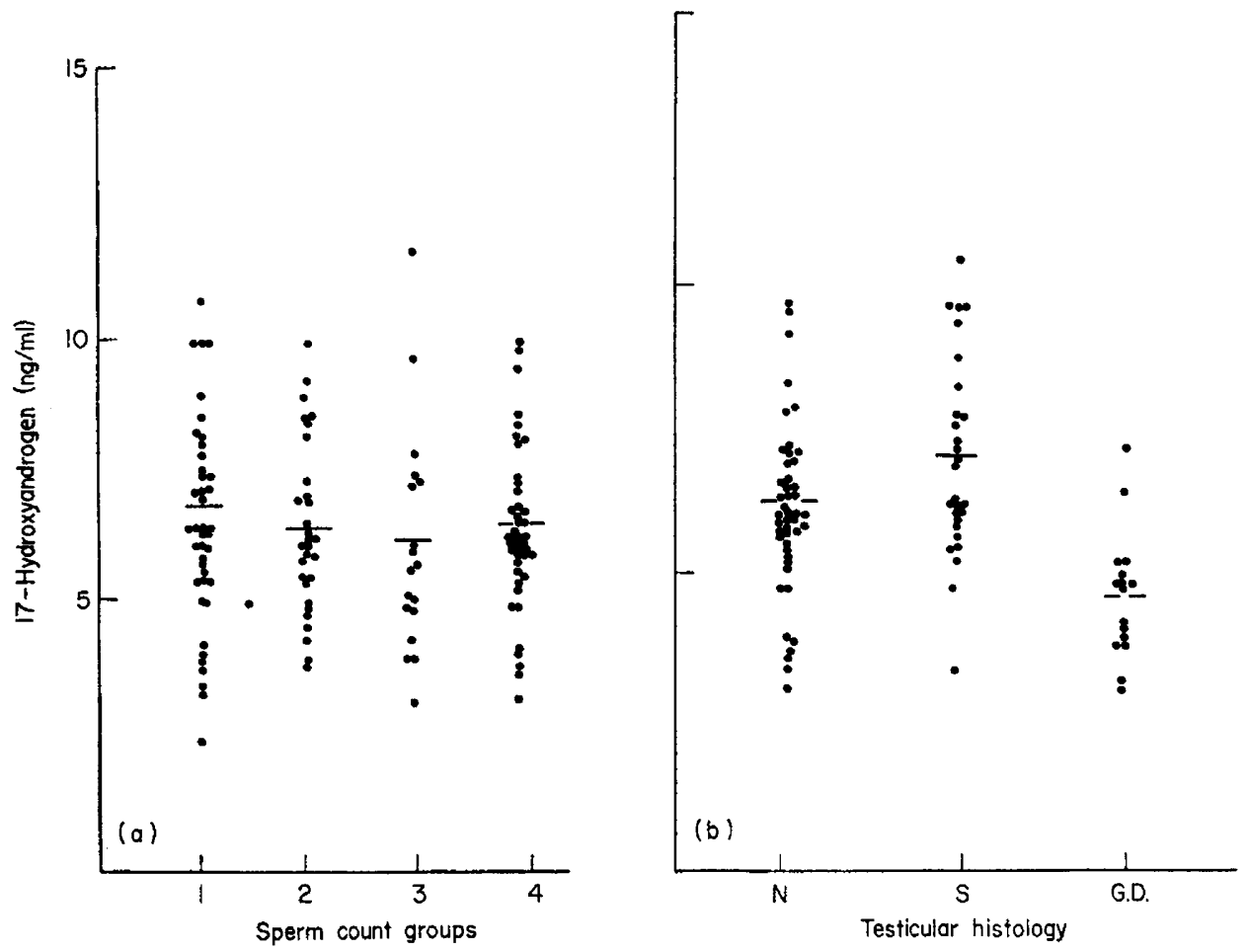

Text-Fig. 1. Correlations of the concentrations of 17-hydroxyandrogens with (a) the sperm count, and (b) the testicular histology. (a) Group 1 : men with $<20 \times 10^{6}$ spermatozoa $/ \mathrm{ml}$; Group 2: men with sperm counts between $20 \times 10^{6}$ and $60 \times 10^{6} / \mathrm{ml}$; Group 3: men with no spermatozoa in their seminal fluid; Group 4: men with $>60 \times 10^{6}$ spermatozoa/ml. (b) $N=$ normal controls; $S=$ men with 'sloughing' in the seminiferous tubules; G.D. = men with germinal defects. 
Text-figure 1(b) shows the correlation of 17-OHA concentrations and testicular histology. The controls were men with sperm counts $>60 \times 10^{6} / \mathrm{ml}$ and spermatozoa of normal motility and morphology. These subjects were not subjected to biopsy but were assumed to have normal testicular histology. Their mean 17-OHA concentration \pm S.D. was $6.52 \pm 1.97 \mathrm{ng} / \mathrm{ml}(\mathrm{N}=46)$, and mean plasma oestradiol- $17 \beta$ concentration was $27 \cdot 2 \pm 18 \mathrm{pg} / \mathrm{ml}(\mathrm{N}=27)$.

The second group were those in which 'sloughing' occurred. The histological diagnosis of sloughing was made on the basis of a disturbance of the orderly sequence of maturation; immature cells were sloughed and were loose in the tubule lumen, so that although mature spermatozoa were formed they could not escape easily from the tubules (Ellis, 1968). This condition is often accompanied by increased peritubular fibrosis and intracellular collagen. These men had a mean \pm S.D. 17-OHA concentration of $7.30 \pm 1.74 \mathrm{ng} / \mathrm{ml} \quad(\mathrm{N}=28)$ and oestradiol- $17 \beta$ concentration of $26 \cdot 2 \pm 6 \mathrm{pg} / \mathrm{ml}(\mathrm{N}=15)$; values which were not significantly different from those of the normal controls.

The third group were patients whose testicular biopsy revealed a germinal defect, such as germinal arrest, or the 'Sertoli cell only' syndrome. In these conditions, no mature spermatozoa are produced and the patients are often azoospermic. The mean \pm S.D. concentration of 17-OHA was significantly $(P<0.005)$ lower $(4.87 \pm 1.07 \mathrm{ng} / \mathrm{ml}(\mathrm{N}=16)$ than that of normal men, and plasma oestradiol-17 $\beta$ concentration in this group was $25 \cdot 6 \pm 9 \mathrm{pg} / \mathrm{ml}(\mathrm{N}=10)$.

From our data, no significant correlation was observed between 17-OHA concentration and sperm count (Text-fig. la). However, low 17-OHA concentrations were found in patients with germinal defects of the testis compared with those of normal men $(P<0.005)$, although clinical signs of hypogonadism were not present, and infertile males with 'sloughing' had higher 17-OHA concentrations than did normal men $(P<0 \cdot 05)$. No significant differences were observed in the oestradiol- $17 \beta$ concentrations of the various groups.

Oral androgen treatment in men with low sperm counts, such as those with 'sloughing', has been shown to be of therapeutic value resulting in increased sperm count, more efficient ejaculation and improved motility (Harvey \& Jackson, 1957). Methyl testosterone, testosterone propionate and, more recently, Mesterolone (Carruthers, 1973; Sommerville \& Hendry, 1973), which appears to act directly on the testis (Wang et al., 1974), have been employed. Testosterone propionate and methyl testosterone suppress the pituitary gonadotrophin secretion, and thus testicular function ceases. On cessation of treatment, a 'spermiogenic rebound phenomenon' is said to occur, and the sperm count often exceeds the pre-treatment levels (Heller et al., 1950; Heckel \& McDonald, 1952).

Androgen therapy is not effective when germinal cell arrest or 'Sertoli cellonly' syndromes are diagnosed. In our study, all the patients with germinal defects, with one exception, had 17-OHA concentrations below $6.50 \mathrm{ng} / \mathrm{ml}$, whereas the majority of patients with sloughing of the germinal epithelium had 17-OHA concentrations above $6.50 \mathrm{ng} / \mathrm{ml}$. Thus, patients with low sperm counts of less than $20 \times 10^{6} / \mathrm{ml}$ whose $17-\mathrm{OHA}$ concentration is greater than $6.50 \mathrm{ng} / \mathrm{ml}$ should be started immediately on oral androgen therapy without the necessity of a testicular biopsy. Testicular biopsy would still be required in 
patients with 17-OHA levels $<6.50 \mathrm{ng} / \mathrm{ml}$ to determine the lesion in the testis. All patients showing azoospermia in all semen collections should be subjected to biopsy since they may be men who have normal testicular function but a mechanical block in the deferent ducts.

The authors would like to acknowledge the assistance of the Department of Pathology, Glasgow Royal Infirmary, for performing sperm counts and examination of the testicular biopsy specimens.

\section{REFERENGES}

Garruthers, G.B. (1973) Clinical studies with Mesterolone on 100 patients. Med. Gynaec. Androl. Sociol. 7, 11-18.

Gharny, C.W. (1956) Treatment of male infertility with large doses of testosterone. F. Am. med. Ass. $160,98-101$.

de la Balze, F.A., Gurtman, A.I., Janches, M., Arrilaga, F., Alvarex, F. \& Segal, L. (1962) Effects of oestrogens on the adult human testis with special reference to the germinal epithelium. A histologic study. F. clin. Endocr. Metab. 22, 1251-1261.

Ellis, J.D. (1968) Testicular biospy. Hosp. Med. pp. 654-658.

HARveY, G. \& Jackson, M.H. (1957) Intermittent methyl testosterone therapy in male infertility. Lancet i, 711-713.

Heckel, N.J. \& MCDonald, J.H. (1952) The rebound phenomena of the spermatogenic activity of the human testis following administration of testosterone propionate. Fert. Steril. 3, 49.

Heller, G.G., Nelson, W.O., Hill, I.B., Henderson, E., Maddock, W.O., Jungck, E.G., Poulsen, G.A. \& MoRtimore, G.E. (1950) Improvement in spermatogenesis following depression of the human testis with testosterone. Fert. Steril. 1, 415-422.

Hillier, S.G., Brownsey, B.C. \& Gameron, E.H.D. (1973) Some observations on the determination of testosterone in human plasma by radioimmunoassay using antisera raised against testosterone3-BSA and testosterone $11 \alpha$-BSA. Steroids $21,735-753$.

LAWrence, D.M. \& SwYre, G.I. (1974) Plasma testosterone and testosterone binding affinities in men with impotence, oligospermia, azoospermia and hypogonadism. Brit. med. F. i, 349-351.

Sommerville, I.T. \& Hendry, W.F. (1973) Some progress in the treatment of male subfertility. Med. Gynaec. Androl. Sociol. 7, 7-10.

Steinberger, E. \& Ducket, G.E. (1967) Hormonal control of spermatogenesis. F. Reprod. Fert., Suppl. 2, $75-87$.

Wang, D., Burger, H.G., De Kretser, D.M., Dulmanis, A., Hudson, B., Keogh, E.J. \& Suthers, M.B. (1974) Effect of Mesterolone on serum FSH, LH and plasma testosterone in normal men. Andrologia 6, 111-118. 